Original

\title{
Hypervariable region structure and polymorphism of mtDNA from dental pulp and a family analysis
}

\author{
Hirofumi Tsutsumi ${ }^{1,2)}$, Toshinobu Komuro ${ }^{1,2)}$, Rei Mukoyama ${ }^{1,2)}$ and Hiroaki Nogami ${ }^{1)}$ \\ ${ }^{1)}$ Department of Legal Medicine, Nihon University School of Dentistry, Tokyo, Japan \\ ${ }^{2}$ Division of Social Dentistry, Dental Research Center, Nihon University School of Dentistry, Tokyo, Japan
}

(Received 19 April and accepted 28 July 2006)

\begin{abstract}
Nucleotide sequences of the hypervariable region in the D-loop of mitochondrial DNA (mtDNA) were analyzed using DNA extracted from 140 old dental pulp samples. These sequences were compared with the sequence reported by Anderson et al. Nucleotide substitution in the HV1 region was identified at 77 positions. A C-to-T transition at position 16223 (C16223T) was most frequently detected $(\mathbf{7 7 . 9 \%})$. Fourteen types of $\mathrm{C}$-stretch sequence patterns were detected and the same sequence as Anderson had the highest frequency (57.9\%). In the HV2 region, base transitions were identified at 56 positions. A263G was identified in all samples. Seven types of $\mathrm{C}$-stretch were detected, but none had the same sequence as Anderson. In the $\mathrm{HV} 3$ region, base transitions were identified at 21 positions. T489C was most frequently identified (64.3\%). Five types of $\mathrm{C}$-stretch were detected, and the same sequence as Anderson accounted for $\mathbf{9 2 . 9 \%}$. The 140 samples were classified into 128 kinds by the sequence patterns of the $\mathrm{HV}$ region. Next, using the blood and oral mucosa epithelium from 23 subjects comprising four generations in a family line, the hereditary relationship of mtDNA was examined. All mtDNA types of the first-generation mother were infallibly inherited by the fourth generation. (J. Oral Sci. $48,145-152,2006$ )
\end{abstract}

Keywords: forensic odontology; dental pulp; mtDNA; hypervariable region; $\mathrm{C}$-stretch; family line.

Correspondence to Dr. Toshinobu Komuro, Department of Legal Medicine, Nihon University School of Dentistry, 1-8-13 KandaSurugadai, Chiyoda-ku, Tokyo 101-8310, Japan

Tel: +81-3-3219-8119

Fax: +81-3-3219-8343

E-mail: komuro@dent.nihon-u.ac.jp

\section{Introduction}

The nucleotide sequences of human mitochondrial DNA (mtDNA) were reported by Anderson et al. in 1981 (1). Of these, hypervariable region 1 (HV1), hypervariable region 2 (HV2) and hypervariable region 3 (HV3) which are rich in polymorphisms in the control region including the displacement loop region (D-loop region) were discovered (2-6).

There are several thousand copies of mtDNA in any cell, which is beneficial since analysis may be undertaken from minute specimens or from old specimens that are contaminated or degraded $(7,8)$. Therefore, the utility of mtDNA in the field of forensic medicine is extremely high. Moreover, mtDNA is transferred via cytoplasmic inheritance or in other words, maternal inheritance. For this reason, it is potentially applicable in the identification of maternal relationship, but since the mtDNA of the father (sperm) is eradicated upon fertilization, mtDNA cannot be used for identification of a paternal relationship (9-11).

The specimens used in forensic investigation are often bloodstains and hair, however, in the case of corpses that have decayed significantly or skeletons, other specimens must be used. Dental pulp that is covered with hard tissue such as dentin or enamel is highly capable of protecting the DNA and is thus extremely useful. Although dental pulp has been used as a sample previously, there have not been any reports which examined polymorphisms of HV1, HV2 and $\mathrm{HV} 3$ including base sequences of $\mathrm{C}$-stretch using this sample.

In this study, using DNA extracted from old dental pulp, the nucleotide sequence polymorphisms of HV1, HV2 and HV3 in the control region of mtDNA were determined in a Japanese population, and its application for personal identification was analyzed. In addition, the genetic 
relationship of the hypervariable region in mtDNA was examined using blood or oral mucosa obtained from 23 people comprising four generations in a family line.

\section{Materials and Methods}

\section{Sample preparation}

Dental pulp samples from 140 unrelated Japanese subjects were used to analyze the nucleotide sequence polymorphism of the hypervariable region in mtDNA Dental pulp samples were obtained from permanent teeth that had been stored at room temperature for 1 to 23 years. Blood or oral mucosa samples from a total of 23 people comprising four generations in a family line which had been stored in the frozen state were also obtained. DNA was extracted using the phenol-chloroform method (12). Prior to DNA analysis, the Ethics Review Committee of Nihon University School of Dentistry had granted ethical approval for the study.

\section{PCR method}

Nucleotides in the mtDNA sequence are numbered according to the sequence reported by Anderson et al. (1), for example nt 16000 .

According to the report of Tsutsumi et al. (13), nt15997 to 16401 of HV1 were amplified by synthesizing forward primer: 5'-CACCATTAGCACCCAAAGCT-3' and reverse primer: 5'-TGATTTCACGGAGGATGGTG-3', and nt29 to 408 of HV2 were amplified by synthesizing forward primer: 5'-GGTCTATCACCCTATTAACCAC-3' and reverse primer: 5'-CTGTTAAAAGTGCATACCGCCA3'. Moreover, nt162 to 639 of HV3 were amplified by synthesizing forward primer: 5'-CGCACCTACGTTC AATATTAC-3' and reverse primer: 5'-GGTGATGTGAG CCCGTCTAA-3'. The PCR reaction mixture used was PCR mixture $3.0 \mu \mathrm{l}, 2.0 \mathrm{mM}$ dNTP mix $3.0 \mu \mathrm{l}, 20 \mathrm{pmol}$ of each primer, Gold Taq DNA polymerase $2 \mathrm{U}$ and $15 \mathrm{ng}$ template DNA to which sterilized water was added to make a total volume of $30 \mu \mathrm{l}$. The initial step of PCR was set at $95^{\circ} \mathrm{C}$ for $9 \mathrm{~min}$, and then thirty cycles $\left(60 \mathrm{sec}\right.$ at $95^{\circ} \mathrm{C}$ for denaturation, $60 \mathrm{sec}$ at $55^{\circ} \mathrm{C}$ for annealing, and $120 \mathrm{sec}$ at $72^{\circ} \mathrm{C}$ for extension) were performed. After the last cycle, the samples were incubated for an additional $7 \mathrm{~min}$ at $72^{\circ} \mathrm{C}$.

\section{Analysis of nucleotide sequence}

The DNA templates for sequence analysis were refined from the PCR products. A total of 3 regions in HV1 (nt16081-16390), HV2 (nt73-354) and HV3 (nt438-594) were sequenced using ABI PRISMTM 310 Genetic Analyzer (Applied Biosystems).

\section{Results}

The nucleotide sequence of each hypervariable region in the 140 samples of dental pulp DNA was compared with the sequence reported by Anderson et al. (1).

\section{Hypervariable region 1}

In nt16081-16390, nucleotide variations (transition, transversion, insertion) occurred at 77 positions (24.8\%). Table 1 - HV1 shows the parts of high frequency. A C-to$\mathrm{T}$ transition at nt16223 (C16223T) that was identified in 109 of the 140 cases (77.9\%) was most frequently found. This was followed by $\mathrm{T} 16362 \mathrm{C}$ with 74 cases $(52.9 \%)$, T16189C with 51 cases (36.4\%), A16183C with 35 cases (25.0\%) and G16129A with 29 cases (20.7\%) in this order.

There were 14 types $(10.0 \%)$ of $\mathrm{C}$ insertion between nt16193 and nt16194 $(* 16193.1 C$ : the asterisk indicates nucleotide absence and 1C means the insertion of one nucleotide $\mathrm{C}$ ).

Moreover, as shown in Table 2 - HV1, 14 cases of sequence patterns of homopolymeric cytosine stretches (Cstretch) were detected between nt16184 and nt16193. Eighty one cases $(57.9 \%)$ with the same structure (CCCCCTCCCC: 5C1T4C) as that reported by Anderson et al. (1) appeared to be the most frequently observed pattern. Following this was $10 \mathrm{C}$ with 28 cases $(20.0 \%)$ and $11 \mathrm{C}$ with 13 cases $(9.3 \%)$ in this order.

The 140 samples were classified into 86 kinds based on the sequence pattern of the HV1 region.

\section{Hypervariable region 2}

In nt73-354, nucleotide variations (transition, transversion, insertion, deletion) occurred at 56 positions (19.9\%). Of these, the parts with a high frequency are shown in Table 1 - HV2. A263G was the mostly frequently observed transition, which was detected in all specimens. This was followed by T310A with 92 cases $(65.7 \%)$, C311A with 63 cases $(45.0 \%)$, C150T with 31 cases (22.1\%) and C312A with 24 cases $(17.1 \%)$ in this order. Examples of insertion were $* 315.1 \mathrm{C}$ in 135 cases $(96.4 \%)$, $* 315.2 \mathrm{C}$ (2C means the insertion of two nucleotides C) in 87 cases $(62.1 \%)$ and $* 315.3 \mathrm{C}$ in 20 cases $(14.3 \%)$. Moreover, cases of nucleotide deletion were found in $0.7 \%$ to $5.0 \%$ of nt 248 , nt 249 , nt 316 and nt 317 (A248del, A249del, G316del, C317del: del means nucleotide deletion).

On the other hand, the C-stretch sequence patterns for nt303-315 were composed of 7 types as shown in Table 2 - HV2. The pattern with the highest frequency was $8 \mathrm{C} 1 \mathrm{~T} 6 \mathrm{C}$ with 63 cases $(45.0 \%)$. This was followed by 7C1T6C with 48 cases $(34.3 \%)$ and 9C1T6C with 20 cases $(14.3 \%)$. There were no cases that indicated the 
Table 1 Characteristic nucleotide variations and frequencies in HV1, HV2 and HV3 regions

\begin{tabular}{|c|c|c|c|c|}
\hline \multicolumn{5}{|l|}{$\mathrm{V} 1$} \\
\hline \multirow{2}{*}{$\begin{array}{l}\begin{array}{l}\text { Nucleotide } \\
\text { position }\end{array} \\
16129\end{array}$} & \multicolumn{2}{|c|}{ Replacement } & \multirow{2}{*}{$\frac{n}{29}$} & \multirow{2}{*}{$\begin{array}{c}\% \\
20.7\end{array}$} \\
\hline & G & $\rightarrow \mathrm{A}$ & & \\
\hline 16172 & $\mathrm{~T}$ & $\rightarrow \mathrm{C}$ & 14 & 10.0 \\
\hline 16182 & A & $\rightarrow \mathrm{C}$ & 11 & 7.9 \\
\hline 16183 & A & $\rightarrow \mathrm{C}$ & 35 & 25.0 \\
\hline 16189 & $\mathrm{~T}$ & $\rightarrow \mathrm{C}$ & 51 & 36.4 \\
\hline 16193.1 & & $\rightarrow \mathrm{C}$ & 14 & 10.0 \\
\hline 16209 & $\mathrm{~T}$ & $\rightarrow \mathrm{C}$ & 15 & 10.7 \\
\hline \multirow[t]{2}{*}{16217} & $\mathrm{~T}$ & $\rightarrow \mathrm{C}$ & 13 & 9.3 \\
\hline & & $\rightarrow \mathrm{A}$ & 1 & 0.7 \\
\hline 16223 & C & $\rightarrow \mathrm{T}$ & 109 & 77.9 \\
\hline 16249 & $\mathrm{~T}$ & $\rightarrow \mathrm{C}$ & 10 & 7.1 \\
\hline 16278 & C & $\rightarrow \mathrm{T}$ & 8 & 5.7 \\
\hline 16290 & C & $\rightarrow \mathrm{T}$ & 8 & 5.7 \\
\hline 16291 & C & $\rightarrow \mathrm{T}$ & 7 & 5.0 \\
\hline 16304 & $\mathrm{~T}$ & $\rightarrow \mathrm{C}$ & 12 & 8.6 \\
\hline 16311 & $\mathrm{~T}$ & $\rightarrow \mathrm{C}$ & 10 & 7.1 \\
\hline 16324 & $\mathrm{~T}$ & $\rightarrow \mathrm{C}$ & 15 & 10.7 \\
\hline 16325 & $\mathrm{~T}$ & $\rightarrow \mathrm{C}$ & 11 & 7.9 \\
\hline 16362 & $\mathrm{~T}$ & $\rightarrow \mathrm{C}$ & 74 & 52.9 \\
\hline 16390 & G & $\rightarrow \mathrm{A}$ & 7 & 5.0 \\
\hline
\end{tabular}

\begin{tabular}{llrr} 
HV2 & & & \\
\hline $\begin{array}{l}\text { Nucleotide } \\
\text { position }\end{array}$ & Replacement & \multicolumn{1}{c}{$\mathrm{n}$} & \multicolumn{1}{c}{$\%$} \\
\hline 76 & $\mathrm{~A} \rightarrow \mathrm{C}$ & 7 & 5.0 \\
& $\rightarrow \mathrm{G}$ & 2 & 1.4 \\
150 & $\mathrm{C} \rightarrow \mathrm{T}$ & 31 & 22.1 \\
152 & $\mathrm{~T} \rightarrow \mathrm{C}$ & 23 & 16.4 \\
194 & $\mathrm{C} \rightarrow \mathrm{T}$ & 12 & 8.6 \\
199 & $\mathrm{~T} \rightarrow \mathrm{C}$ & 20 & 14.3 \\
207 & $\mathrm{G} \rightarrow \mathrm{A}$ & 8 & 5.7 \\
248 & $\mathrm{~A} \rightarrow \mathrm{del}$ & 1 & 0.7 \\
249 & $\mathrm{~A} \rightarrow \mathrm{del}$ & 7 & 5.0 \\
263 & $\mathrm{~A} \rightarrow \mathrm{G}$ & 140 & 100.0 \\
310 & $\mathrm{~T} \rightarrow \mathrm{A}$ & 92 & 65.7 \\
311 & $\mathrm{C} \rightarrow \mathrm{A}$ & 63 & 45.0 \\
312 & $\mathrm{C} \rightarrow \mathrm{A}$ & 24 & 17.1 \\
315.1 & $* \rightarrow \mathrm{C}$ & 135 & 96.4 \\
315.2 & $* \rightarrow \mathrm{C}$ & 87 & 62.1 \\
315.3 & $* \rightarrow \mathrm{C}$ & 20 & 14.3 \\
316 & $\mathrm{G} \rightarrow \mathrm{del}$ & 1 & 0.7 \\
317 & $\mathrm{C} \rightarrow$ del & 6 & 4.3 \\
\hline
\end{tabular}

\begin{tabular}{llrr} 
HV3 & & & \\
\hline $\begin{array}{l}\text { Nucleotide } \\
\text { position }\end{array}$ & Replacement & $\mathrm{n}$ & \multicolumn{1}{c}{$\%$} \\
\hline 489 & $\mathrm{~T} \rightarrow \mathrm{C}$ & 90 & 64.3 \\
522 & $\mathrm{C} \rightarrow$ del & 46 & 32.9 \\
523 & $\mathrm{~A} \rightarrow$ del & 46 & 32.9 \\
568.1 & $* \rightarrow \mathrm{C}$ & 7 & 5.0 \\
\hline
\end{tabular}

n: No. observed, *: Nucleotide absence, del: Nucleotide deletion, $\mathrm{N}=140$

Table 2 C- stretch sequences and frequencies of HV1, HV2 and HV3 regions

\begin{tabular}{|c|c|c|c|c|c|c|c|c|c|c|c|c|c|}
\hline Nucleotide position & 16184 & 16185 & 16186 & 16187 & 16188 & 16189 & 16190 & 16191 & 16192 & 16193 & 16193.1 & & 0 \\
\hline Anderson's sequence & $\mathrm{C}$ & $\mathrm{C}$ & $\mathrm{C}$ & $\mathrm{C}$ & $\mathrm{C}$ & $\mathrm{T}$ & $\mathrm{C}$ & $\mathrm{C}$ & $\mathrm{C}$ & $\mathrm{C}$ & & n & $\%$ \\
\hline $\begin{array}{l}\text { This study's } \\
\text { sequence }\end{array}$ & $\begin{array}{l}\mathrm{T} \\
\mathrm{T} \\
\mathrm{C} \\
\mathrm{C} \\
\mathrm{C} \\
\mathrm{C} \\
\mathrm{C} \\
\mathrm{C} \\
\mathrm{C} \\
\mathrm{C} \\
\mathrm{C} \\
\mathrm{C} \\
\mathrm{C} \\
\mathrm{C}\end{array}$ & $\begin{array}{l}\mathrm{C} \\
\mathrm{C} \\
\mathrm{T} \\
\mathrm{C} \\
\mathrm{C} \\
\mathrm{C} \\
\mathrm{C} \\
\mathrm{C} \\
\mathrm{C} \\
\mathrm{C} \\
\mathrm{C} \\
\mathrm{C} \\
\mathrm{C} \\
\mathrm{C}\end{array}$ & $\begin{array}{l}\mathrm{C} \\
\mathrm{C} \\
\mathrm{C} \\
\mathrm{C} \\
\mathrm{C} \\
\mathrm{C} \\
\mathrm{C} \\
\mathrm{C} \\
\mathrm{C} \\
\mathrm{C} \\
\mathrm{C} \\
\mathrm{C} \\
\mathrm{C} \\
\mathrm{C}\end{array}$ & $\begin{array}{l}\mathrm{C} \\
\mathrm{C} \\
\mathrm{C} \\
\mathrm{T} \\
\mathrm{T} \\
\mathrm{T} \\
\mathrm{C} \\
\mathrm{C} \\
\mathrm{C} \\
\mathrm{C} \\
\mathrm{C} \\
\mathrm{C} \\
\mathrm{C} \\
\mathrm{C}\end{array}$ & $\begin{array}{l}\mathrm{T} \\
\mathrm{C} \\
\mathrm{C} \\
\mathrm{C} \\
\mathrm{C} \\
\mathrm{C} \\
\mathrm{T} \\
\mathrm{T} \\
\mathrm{C} \\
\mathrm{C} \\
\mathrm{C} \\
\mathrm{C} \\
\mathrm{C} \\
\mathrm{C}\end{array}$ & $\begin{array}{l}\mathrm{C} \\
\mathrm{T} \\
\mathrm{T} \\
\mathrm{T} \\
\mathrm{C} \\
\mathrm{C} \\
\mathrm{C} \\
\mathrm{C} \\
\mathrm{T} \\
\mathrm{T} \\
\mathrm{C} \\
\mathrm{C} \\
\mathrm{C} \\
\mathrm{C}\end{array}$ & $\begin{array}{l}\mathrm{C} \\
\mathrm{C} \\
\mathrm{C} \\
\mathrm{C} \\
\mathrm{C} \\
\mathrm{C} \\
\mathrm{C} \\
\mathrm{C} \\
\mathrm{C} \\
\mathrm{C} \\
\mathrm{C} \\
\mathrm{C} \\
\mathrm{C} \\
\mathrm{C}\end{array}$ & $\begin{array}{l}\text { C } \\
\text { C } \\
\text { C } \\
\text { C } \\
\text { C } \\
\text { C } \\
\text { C } \\
\text { C } \\
\text { C } \\
\text { C } \\
\text { C } \\
\text { C } \\
\text { C } \\
\text { C }\end{array}$ & $\begin{array}{l}\mathrm{C} \\
\mathrm{C} \\
\mathrm{C} \\
\mathrm{C} \\
\mathrm{C} \\
\mathrm{C} \\
\mathrm{C} \\
\mathrm{C} \\
\mathrm{T} \\
\mathrm{C} \\
\mathrm{T} \\
\mathrm{C} \\
\mathrm{C} \\
\mathrm{C}\end{array}$ & $\begin{array}{c}\text { del } \\
\text { C } \\
\text { C } \\
\text { C } \\
\text { del } \\
\text { C } \\
\text { C } \\
\text { C } \\
\text { C } \\
\text { C } \\
\text { C } \\
\text { del } \\
\text { C } \\
\text { C }\end{array}$ & $\mathrm{C}$ & $\begin{array}{r}1 \\
1 \\
2 \\
4 \\
1 \\
1 \\
1 \\
1 \\
1 \\
81 \\
2 \\
3 \\
28 \\
13\end{array}$ & $\begin{array}{r}0.7 \\
0.7 \\
1.4 \\
2.9 \\
0.7 \\
0.7 \\
0.7 \\
0.7 \\
0.7 \\
57.9 \\
1.4 \\
2.1 \\
20.0 \\
9.3\end{array}$ \\
\hline
\end{tabular}

HV2

\begin{tabular}{|c|c|c|c|c|c|c|c|c|c|c|c|c|c|c|c|c|c|c|}
\hline Nucleotide position & 303 & 304 & 305 & 306 & 307 & 308 & 309 & 310 & 311 & 312 & 313 & 314 & 315 & 315.1 & 315.2 & 315.3 & n & $\%$ \\
\hline Anderson's sequence & $\mathrm{C}$ & $\mathrm{C}$ & $\mathrm{C}$ & $\mathrm{C}$ & $\mathrm{C}$ & $\mathrm{C}$ & $\mathrm{C}$ & $\mathrm{T}$ & C & $\mathrm{C}$ & C & C & C & & & & (1) & 0 \\
\hline $\begin{array}{l}\text { This study's } \\
\text { sequence }\end{array}$ & $\begin{array}{l}\mathrm{C} \\
\mathrm{C} \\
\mathrm{C} \\
\mathrm{C} \\
\mathrm{C} \\
\mathrm{C} \\
\mathrm{C}\end{array}$ & $\begin{array}{l}\mathrm{C} \\
\mathrm{C} \\
\mathrm{C} \\
\mathrm{C} \\
\mathrm{C} \\
\mathrm{C} \\
\mathrm{C}\end{array}$ & $\begin{array}{l}\mathrm{C} \\
\mathrm{C} \\
\mathrm{C} \\
\mathrm{C} \\
\mathrm{C} \\
\mathrm{C} \\
\mathrm{C}\end{array}$ & $\begin{array}{l}\mathrm{C} \\
\mathrm{C} \\
\mathrm{C} \\
\mathrm{C} \\
\mathrm{C} \\
\mathrm{C} \\
\mathrm{C}\end{array}$ & $\begin{array}{l}\mathrm{C} \\
\mathrm{C} \\
\mathrm{C} \\
\mathrm{C} \\
\mathrm{C} \\
\mathrm{C} \\
\mathrm{C}\end{array}$ & $\begin{array}{l}\mathrm{C} \\
\mathrm{C} \\
\mathrm{C} \\
\mathrm{C} \\
\mathrm{C} \\
\mathrm{C} \\
\mathrm{C}\end{array}$ & $\begin{array}{l}\mathrm{T} \\
\mathrm{C} \\
\mathrm{C} \\
\mathrm{C} \\
\mathrm{C} \\
\mathrm{C} \\
\mathrm{C}\end{array}$ & $\begin{array}{l}\mathrm{C} \\
\mathrm{T} \\
\mathrm{C} \\
\mathrm{C} \\
\mathrm{C} \\
\mathrm{C} \\
\mathrm{C}\end{array}$ & $\begin{array}{l}\mathrm{C} \\
\mathrm{C} \\
\mathrm{T} \\
\mathrm{C} \\
\mathrm{C} \\
\mathrm{C} \\
\mathrm{C}\end{array}$ & $\begin{array}{l}\mathrm{C} \\
\mathrm{C} \\
\mathrm{C} \\
\mathrm{T} \\
\mathrm{T} \\
\mathrm{C} \\
\mathrm{C}\end{array}$ & $\begin{array}{l}\mathrm{C} \\
\mathrm{C} \\
\mathrm{C} \\
\mathrm{C} \\
\mathrm{C} \\
\mathrm{C} \\
\mathrm{C}\end{array}$ & $\begin{array}{c}\mathrm{C} \\
\mathrm{C} \\
\mathrm{C} \\
\mathrm{C} \\
\mathrm{C} \\
\mathrm{del} \\
\mathrm{C}\end{array}$ & $\begin{array}{c}\mathrm{C} \\
\mathrm{C} \\
\mathrm{C} \\
\mathrm{C} \\
\mathrm{C} \\
\mathrm{del} \\
\mathrm{C}\end{array}$ & $\begin{array}{l}\mathrm{C} \\
\mathrm{C} \\
\mathrm{C} \\
\mathrm{C}\end{array}$ & $\begin{array}{l}\mathrm{C} \\
\mathrm{C} \\
\mathrm{C}\end{array}$ & $\mathrm{C}$ & $\begin{array}{r}1 \\
48 \\
63 \\
4 \\
20 \\
1 \\
3\end{array}$ & $\begin{array}{r}0.7 \\
34.3 \\
45.0 \\
2.9 \\
14.3 \\
0.7 \\
2.1\end{array}$ \\
\hline
\end{tabular}

\begin{tabular}{|c|c|c|c|c|c|c|c|c|c|c|c|c|c|c|c|}
\hline Nucleotide position & 568 & 569 & 570 & 571 & 572 & 573 & 573.1 & 573.2 & 573.3 & 573.4 & 573.5 & 573.6 & 573.7 & . & 0 \\
\hline Anderson's sequence & $\mathrm{C}$ & $\mathrm{C}$ & $\mathrm{C}$ & $\mathrm{C}$ & $\mathrm{C}$ & $\mathrm{C}$ & & & & & & & & $\mathrm{n}$ & $\%$ \\
\hline $\begin{array}{l}\text { This study's } \\
\text { sequence }\end{array}$ & $\begin{array}{l}\mathrm{C} \\
\mathrm{C} \\
\mathrm{C} \\
\mathrm{C} \\
\mathrm{C}\end{array}$ & $\begin{array}{l}\mathrm{C} \\
\mathrm{C} \\
\mathrm{C} \\
\mathrm{C} \\
\mathrm{C}\end{array}$ & $\begin{array}{l}\mathrm{C} \\
\mathrm{C} \\
\mathrm{C} \\
\mathrm{C} \\
\mathrm{C}\end{array}$ & $\begin{array}{l}\mathrm{C} \\
\mathrm{C} \\
\mathrm{C} \\
\mathrm{C} \\
\mathrm{C}\end{array}$ & $\begin{array}{l}\mathrm{C} \\
\mathrm{C} \\
\mathrm{C} \\
\mathrm{C} \\
\mathrm{C}\end{array}$ & $\begin{array}{l}\mathrm{C} \\
\mathrm{C} \\
\mathrm{C} \\
\mathrm{C} \\
\mathrm{C}\end{array}$ & $\begin{array}{l}\mathrm{C} \\
\mathrm{C} \\
\mathrm{C} \\
\mathrm{C}\end{array}$ & $\begin{array}{l}\mathrm{C} \\
\mathrm{C} \\
\mathrm{C}\end{array}$ & $\begin{array}{l}\mathrm{C} \\
\mathrm{C} \\
\mathrm{C}\end{array}$ & $\begin{array}{l}\mathrm{C} \\
\mathrm{C}\end{array}$ & $\begin{array}{l}\mathrm{C} \\
\mathrm{C}\end{array}$ & $\begin{array}{l}\mathrm{C} \\
\mathrm{C}\end{array}$ & $\mathrm{C}$ & $\begin{array}{r}130 \\
1 \\
4 \\
2 \\
3\end{array}$ & $\begin{array}{r}92.9 \\
0.7 \\
2.9 \\
1.4 \\
2.1\end{array}$ \\
\hline
\end{tabular}

n: No. observed, del: Nucleotide deletion, $N=140$ 
same structure as that reported by Anderson et al. (1).

The 140 samples were classified into 75 kinds based on the sequence pattern of the HV2 region.

\section{Hypervariable region 3}

In nt438-594, nucleotide variations (transition, deletion, insertion) occurred at 21 positions (13.4\%). T489C was the most frequently detected nucleotide transition with 90 cases $(64.3 \%)$ (Table 1 - HV3). This was followed by nt522 and nt523 that showed nucleotide deletion with 46 cases each (32.9\% for both) (C522del, A523del). In the case of nt568.1, nucleotide insertion was identified $(* 568.1 \mathrm{C})$.

In nt568-573, there were 5 types of C-stretch sequence patterns as shown in Table 2-HV3. Of these, 130 cases $(92.9 \%)$ showed the same structure (6C) as that reported by Anderson et al. (1), and the others indicated nucleotide insertion of between 1 and 7 nucleotides. Moreover, in HV3, there were 46 cases that indicated both $\mathrm{C} 522 \mathrm{del}$ and A523del and of these, 33 cases were 8C1T6C with the highest frequency $(45.0 \%)$ of $\mathrm{C}$-stretch nucleotide sequence in nt303-315 of the HV2 region as shown in Table 2 - HV2.

The 140 samples were classified into 20 kinds based on the sequence pattern of the HV3 region.

As stated above, the 140 samples were classified into 128 kinds based on the sequence patterns of the three HV regions.

\section{Polymorphism in a family line}

PCR amplification was performed on the three HV regions in the mtDNA from 23 people comprising four generations in a single family line (first generation: father and mother; second generation: 5 children and 4 spouses of the children; third generation: 9 grandchildren and 1 spouse of a grandchild; fourth generation: 2 greatgrandchildren).

The nucleotide sequence of the mother in the first generation was compared with the findings reported by Anderson et al. (1). With respect to the HV1 region, nucleotide transition was identified as C16223T and T16362C (Fig. 1 - HV1). The variations identified in the HV1 region were limited to this part and other sequences coincided with those reported by Anderson et al. (1). The frequency was 14 cases (10\%) among 140 cases of dental pulp DNA. Moreover, C-stretch of 5C1T4C was identified in nt16184-16193. The frequency was 81 (57.9\%) among the 140 cases.

With respect to the HV2 region, variations were identified at 6 positions that had the sequence A73G-C194T-A263GT310C-C311T-*315.2C (Fig. 1 - HV2) and of the other sequences coincided with the report of Anderson et al. (1) in $5(3.6 \%)$ of the 140 cases. Moreover, C-stretch was identified for 8C1T6C at nt303-315 in 63 (45.0\%) of the 140 cases.

Furthermore, in the HV3 region, variations were identified at three positions with the sequence of T489CC522del-A523del (Fig. 1 - HV3) and the other sequences coincided with the sequence reported by Anderson et al. (1) in $10(7.1 \%)$ of the 140 cases. Moreover, C-stretch was identified for $6 \mathrm{C}$ at nt570-575 in $130(92.9 \%)$ of the 140 cases.

From the above findings, 2 samples of the 140 cases of dental pulp DNA (1.43\%) showed the same pattern as the HV1, HV2 and HV3 regions in the mother of the first generation.

The genealogical tree of the 23 people is shown in Fig. 2. The sequence comparison between this study and Anderson's results indicated that the sequence of the mother in the first generation was inherited by the children [five: 3 males $($ No.3, 5, 7), 2 females $($ No.10, 11)] in the second generation, grandchildren [2 females (No.19, 20)] in the third generation and the great-grandchildren [two: 1 male (No.23), 1 female (No.22)] in the fourth generation (Fig. 2: bold line).

\section{Discussion}

In the area of forensic investigation, the specimens used are usually highly damaged and difficulties are often experienced in DNA identification. However, even if examination using the genetic polymorphism of nuclear DNA with few copies as reference is not feasible, there are a number of cases in which examination using the genetic polymorphism of mtDNA with several thousand copies as reference is in fact possible. This is because by viewing the variations such as nucleotide transition in the hypervariable region found in 3 positions of the control region as haplotypes, precision of personal identification may improve (14).

As dental pulp DNA is enclosed in hard tissue, the state of storage of DNA is extremely good, and thus is an ideal specimen for identification. Successful identification was reported using dental pulp from a corpse that had been left underwater for 7 months (15). While the reliability of the results of identification is high if the specimen is blood, when the dental pulp of a decomposed or skeletonized body is the specimen, the impact of heteroplasmy due to various bacteria cannot be disregarded (16). For this reason, mtDNA polymorphism using old dental pulp was analyzed in the present study for personal identification of decomposed or skeletonized bodies.

First, with a total of 140 cases of old dental pulp, analysis of polymorphism in the HV1 region was performed. 
Sequence analysis was possible for all specimens. As shown in Fig. 1 - HV2, there were cases in which heteroplasmy at nt316 of C-stretch was identified, but this did not affect the analysis. The proportion of manifestation of heteroplasmy is said to differ not only among relatives on the maternal side (17) but also within individuals
(16,18-20), and hence, caution is advised during analysis. In actual identification, multiple analyses are necessary so that the possibility of variation by an error of Taq polymerase is considered (21).

Compared to the nucleotide sequence identified by Anderson et al. (1) using blood, as shown in Table 1,

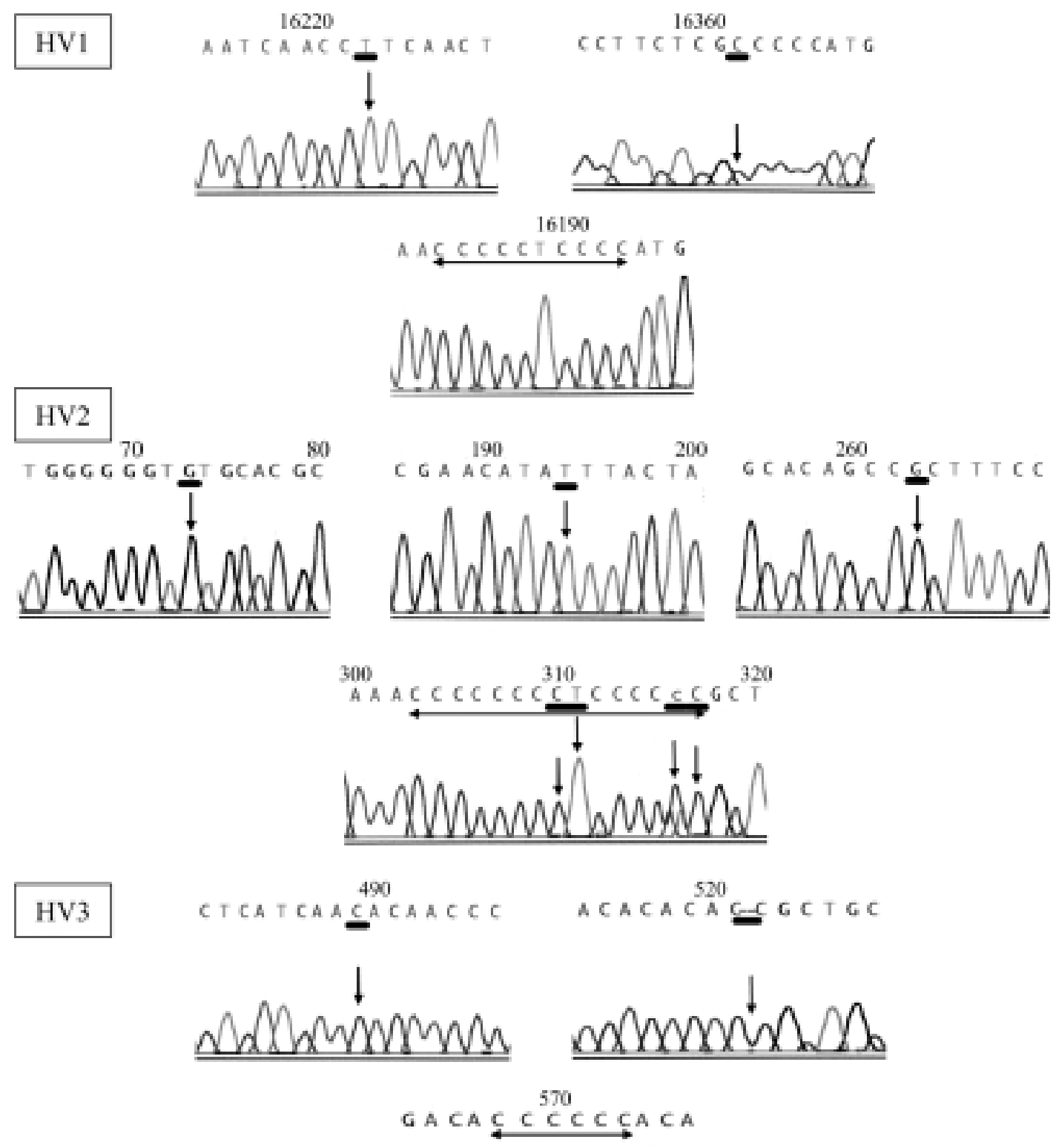

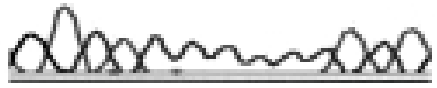

Fig. 1 Sequence variations of HV1, HV2 and HV3 regions in the mother of the first generation. In HV1 region, nucleotide transitions were identified from C toT $(\downarrow)$ at nt16223 and from T to C at t16362 $(\downarrow)$. C-stretch of nt16184 to nt16193 ( $\longleftrightarrow)$ showed the same structure (CCCCCTCCCC: 5C1T4C) as that reported by Anderson et al. In HV2 region, nucleotide transition was identified from A to $\mathrm{G}$ at nt73, $\mathrm{C}$ to $\mathrm{T}$ at nt194, A to $\mathrm{G}$ at nt263, $\mathrm{T}$ to $\mathrm{C}$ at nt310 and $\mathrm{C}$ to $\mathrm{T}$ at nt311. Moreover, two bases $\mathrm{C}$ insert at nt315.1 and nt315.2. Heteroplasmy was detected at nt315.1. C-stretch of nt303 to nt317 was 8C1T6C. In HV3 region, nucleotide transition was identified from $\mathrm{T}$ to $\mathrm{C}$ at nt489. Cytosine and adenine delete at nt522 and at nt523, respectively. C-stretch of nt568 to nt573 showed the same structure (6C) as that reported by Anderson et al. (1). 


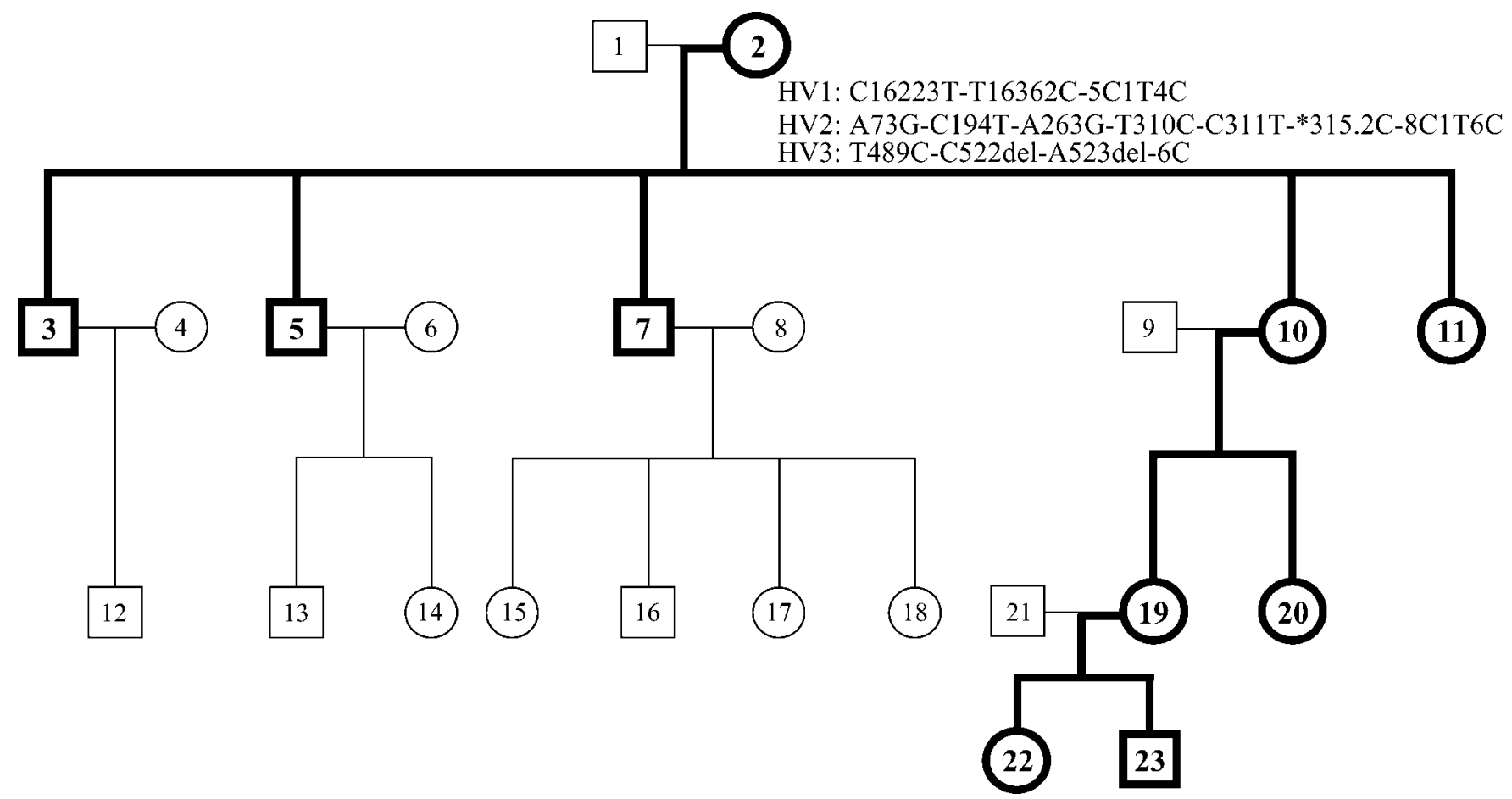

Fig. 2 Genealogical tree and the heredity relations of hypervariable region (HV1, HV2 and HV3) in mtDNA. Bold numbers (heavy line) indicate heredity of the sequence of the mother in the first generation.

C16223T that is reported to have high frequency (13) accounts for $77.9 \%$. This is followed by $\mathrm{T} 16362 \mathrm{C}$ with $52.9 \%$, T16189C with $36.4 \%$ and A16183C with $25.0 \%$ in this order. Nishimaki et al. (22) who studied 150 blood samples of Japanese people reported that the frequency of $\mathrm{C} 16223 \mathrm{~T}$ was $82.6 \%$, $\mathrm{T} 16362 \mathrm{C}$ was $43 \%, \mathrm{G} 16129 \mathrm{~A}$ was $31.1 \%$ and that of $\mathrm{A} 16183 \mathrm{C}$ was $14.7 \%$ in this order. There was no significant difference between the two results. Moreover, they also studied 120 blood samples of Chinese people. While the frequencies of T16362C, G16129A and A16173C were about the same, they reported that the frequency of $\mathrm{C} 16223 \mathrm{~T}$ was $62.5 \%$. This indicates that the high frequency of a C-to-T transition at nt16223 is characteristic of Japanese people. On the other hand, a T-to-A transversion at nt16217 is infrequent, but is extremely effective for personal identification, if detected.

Fourteen types of sequence patterns of C-stretch were identified for nt16184-16193 (Table 2 - HV1). Eighty-one cases or $57.9 \%$ showed the same structure (5C1T4C) as that reported by Anderson et al. This was followed by 41 cases (29.3\%) of combined $10 \mathrm{C}$ and $11 \mathrm{C}$ being manifested and these three types accounted for about $90 \%$ of the total. Therefore, it is understood that if a DNA type other than these three types is detected, this would be useful for personal identification.

Next, having analyzed polymorphism in the HV2 region, A263G was observed in all 140 cases. For this reason, it may be considered that nt263 is guanine in the case of the Japanese people. In the event of a different nucleotide being found in this region, it may thus be considered that the identity of the body is other than ethnic Japanese. It seems that a difference in the position of nucleotide substitution is helpful in analysis in human genetics to characterize races. Moreover, 135 cases $(96.4 \%)$ of *315.1C were identified. This finding is also believed to be characteristic of the Japanese. On the other hand, in nt76, samples of A-to-C transversion and of A-to-G transition were identified. Moreover, the frequencies of A248 and of G316del were low and thus, these deletions may be effective for personal identification.

With respect to the sequence pattern of C-stretch in nt303-315, there were no cases that showed the same structure (7C1T5C) as that reported by Anderson et al., and this finding is thought to be characteristic of the Japanese. The 8C1T6C, 7C1T6C and 9C1T6C patterns amount to approximately $95 \%$ showing a slant, but these were detected more or less equivalently. In addition, the samples that showed $6 \mathrm{C} 1 \mathrm{~T} 6 \mathrm{C}$ and $11 \mathrm{C} 2 \mathrm{del}$ accounted for only $0.7 \%$ (1 case). Detection of such a finding will enhance the reliability of identification.

Moreover, as a result of performing analysis on the polymorphism in the $\mathrm{HV} 3$ region, $\mathrm{T} 489 \mathrm{C}$ was detected in 90 cases $(64.3 \%)$. C522del and A523del were detected in 46 samples each, and these findings were characteristic. 
With respect to the sequence pattern of C-stretch in nt568573,130 cases $(92.9 \%)$ had the same structure (6C) as that reported by Anderson et al. and the fact that almost all exhibited this pattern may also be considered a characteristic specific to the Japanese.

Of the 46 cases in which nucleotide deletion was recognized at nt522 and nt523, 33 cases showed C-stretch of $8 \mathrm{C} 1 \mathrm{~T} 6 \mathrm{C}$ in the HV2 region. This finding can be considered important in personal identification.

The 140 samples were classified into 128 kinds based on the sequence patterns of the three HV regions. As stated above, it was recognized that personal identification by polymorphism analysis of the hypervariable region in mtDNA extracted from old dental pulp is extremely useful. The use of DNA analysis is not limited to the area of forensic medicine and it is often used as a method in personal identification and confirmation of blood relationship in the areas of anthropology and archeology (23-25). In particular, analysis of mtDNA polymorphism is an effective method in tracking relationships with a deceased person. This is because mtDNA types are inherited from the mother. In 1994, it was reported that the analysis of autosomal STR and mtDNA was performed to confirm the identity of the corpses of Nicholas II, the last Czar of Imperial Russia and his family (11). There have apparently been no other reports investigating a single family tree using the hypervariable region in mtDNA. Hence, the samples gathered from 23 people comprising 4 generations of a single family line were considered extremely valuable in investigating a family line.

MtDNA types of the mother in the first generation were determined as C16223T-T16362C-5C1T4C in the HV1 region, A73G-C194T-A263G-T310C-C311T- *315.2C$8 \mathrm{C} 1 \mathrm{~T} 6 \mathrm{C}$ in the HV2 region and T489C-C522del-A523del$6 \mathrm{C}$ in the HV3 region. These haplotypes of the mother in the first generation were inherited without mutation by all five brothers and sisters in the second generation ( 3 male children and 2 female children). One girl got married and delivered two girls who comprise the third generation. Furthermore, girl No.19 delivered one male and one female who make the fourth generation. It was reported that the mutation rate of mtDNA was 5 to 10 times higher than that of nucleus DNA (26), but, in this study, all mtDNA types of the first-generation mother were inherited by the fourth generation without fail (Fig. 2: bold line). In the future, we plan to analyze a wider range of nucleotide sequences and examine the presence of variations.

\section{Acknowledgments}

This work was supported in part by a Grant from the Dental Research Center, Nihon University School of
Dentistry in 2004 and 2005, by the Sato Fund, Nihon University School of Dentistry in 2004, and by a Grantin-Aid for Exploratory Research, MEXT KAKENHI (17659665) in 2005.

\section{References}

1. Anderson S, Bankier AT, Barrell BG, de Bruijn MHL, Coulson AR, Drouin J, Eperon IC, Nierlich DP, Roe BA, Sanger F, Schreier PH, Smith AJH, Staden R, Young IG (1981) Sequence and organization of the human mitochondrial genome. Nature 290, 457-465

2. Horai S, Hayasaka K (1990) Intraspecific nucleotide sequence differences in the major noncoding region of human mitochondrial DNA. Am J Hum Genet 46, 828-842

3. Piercy R, Sullivan KM, Benson N, Gill P (1993) The application of mitochondrial DNA typing to the study of white Caucasian genetic identification. Int J Legal Med 106, 85-90

4. Seo Y, Stradmann-Bellinghausen B, Rittner C, Takahama K, Schneider PM (1998) Sequence polymorphism of mitochondrial DNA control region in Japanese. Forensic Sci Int 97, 155-164

5. Imaizumi K, Parsons TJ, Yoshino M, Holland MM (2002) A new database of mitochondrial DNA hypervariable regions I and II sequences from 162 Japanese individuals. Int J Legal Med 116, 68-73

6. Lutz S, Wittig H, Weisser HJ, Heizmann J, Junge A, Dimo-Simonin N, Parson W, Edelmann J, Anslinger K, Jung S, Augustin C (2000) Is it possible to differentiate mtDNA by means of HVIII in samples that cannot be distinguished by sequencing the HVI and HVII regions? Forensic Sci Int 113, 97101

7. Lutz S, Weisser HJ, Heizmann J, Pollak S (1996) mtDNA as a tool for identification of human remains. Identification using mtDNA. Int J Legal Med 109, 205-209

8. Koyama H, Iwasa M, Ohtani S, Ohira H, Tsuchimochi T, Maeno Y, Isobe I, Matsumoto T, Yamada Y, Nagao M (2002) Personal identification from human remains by mitochondrial DNA sequencing. Am J Forensic Med Pathol 23, 272-276

9. Giles RE, Blanc H, Cann HM, Wallace DC (1980) Maternal inheritance of human mitochondrial DNA. Proc Natl Acad Sci USA 77, 6715-6719

10. Nishimura Y, Yoshinari T, Naruse K, Yamada T, Sumi K, Mitani H, Higashiyama T, Kuroiwa T (2006) Active digestion of sperm mitochondrial DNA in single living sperm revealed by optical 
tweezers. Proc Natl Acad Sci USA 103, 1382-1387

11. Gill P, Ivanov PL, Kimpton C, Piercy R, Benson N, Tully G, Evett I, Hagelberg E, Sullivan K (1994) Identification of the remains of the Romanov family by DNA analysis. Nat Genet 6, 130-135

12. Hochmeister MN, Budowle B, Borer UV, Dirnhofer $\mathrm{R}$ (1995) A method for the purification and recovery of genomic DNA from an HLA DQA1 amplification product and its subsequent amplification and typing with the AmpliType ${ }^{\circledR}$ PM PCR Amplification and Typing Kit. J Forensic Sci 40, 649-653

13. Tsutsumi H, Mukoyama R, Komuro T (2004) Mitochondrial DNA polymorphism from dental pulp. In DNA Polymorphism, Vol 12, Nippon DNA Takei Gakkai, Takatori T eds, Toyo Shoten, Tokyo, 249-251 (in Japanese)

14. Koyama H, Iwasa M, Maeno Y, Tsuchimochi T, Isobe I, Seko-Nakamura Y, Monma-Ohtaki J, Matsumoto T, Ogawa S, Sato B, Nagao M (2002) Mitochondrial sequence haplotype in the Japanese population. Forensic Sci Int 24, 93-96

15. Ohira H, Yamada Y, Yamamoto I, Ohtani S, Yukawa N, Takeichi S (2001) Identification applying mitochondrial DNA analysis from teeth of a drowned body that existed in water for a long term. In DNA Polymorphism, Vol 9, Nippon DNA Takei Gakkai, Takeichi S eds, Toyo Shoten, Tokyo, 132-134 (in Japanese)

16. Katsumura S, Sato K, Ohshima T, Maeda N (2005) Characteristic of mtDNA polymorphism from human intraoral tissues. In DNA Polymorphism, Vol 13, Nippon DNA Takei Gakkai, Kobayashi T eds, Toyo Shoten, Tokyo, 49-52 (in Japanese)

17. Parsons TJ, Muniec DS, Sullivan K, Woodyatt N, Alliston-Greiner R, Wilson MR, Berry DL, Holland KA, Weedn VW, Gill P, Holland MM (1997) A high observed substitution rate in the human mitochondrial DNA control region. Nat Genet 15, 363-368

18. Bendall KE, Macaulay VA, Sykes BC (1997) Variable levels of a heteroplasmic point mutation in individual hair roots. Am J Hum Genet 61, 13031308

19. Wilson MR, Polanskey D, Replogle J, DiZinno JA, Budowle B (1997) A family exihiting heteroplasmy in the human mitochondrial DNA control region reveals both somatic mosaicism and pronounced segregation of mitotypes. Hum Genet 100, 167171

20. Grzybowski T (2000) Extremely high levels of human mitochondrial DNA heteroplasmy in single hair roots. Electrophoresis 21, 548-553

21. Hamilton SC, Farchaus JW, Davis MC (2001) DNA polymerase as engines for biotechnology. Biotechniques 31, 370-383

22. Nishimaki Y, Sato K, Fang L, Ma M, Hasekura H, Boettcher B (1999) Sequence polymorphism in the mtDNA HV1 region in Japanese and Chinese. Legal Med 1, 238-249

23. Horai S, Hayasaka K, Murayama K, Wate N, Koike H, Nakai N (1989) DNA amplification from ancient human skeletal remains and their sequence analysis. Proc Jpn Acad Ser B 65, 229-233

24. Uchihi R, Yamamoto T, Nozawa H, Tamaki K, Ozawa T, Yamada TK, Katsumata Y (1998) DNA analysis of a grandfather-father-son relationship from 300-year-old remains of the Date clan in Japan. Jpn J Legal Med 52, 157-162

25. Dodo Y, Kawakubo Y (2002) Cranial affinities of the Epi-Jomon inhabitants in Hokkaido, Japan. Anthropol Sci 110, 1-32

26. Brown WM, George M Jr, Wilson AC (1979) Rapid evolution of animal mitochondrial DNA. Proc Natl Acad Sci USA 76, 1967-1971 